after a jejunoileal shunt, however, unlike that with most dietary regimens, is usually both substantial and sustained, so that the effect of weight reduction on blood pressure is more apparent.

I thank Professor J R A Mitchell for constructive criticism of this paper, Miss Jayne Patrick for typing the manuscript, and the department of clinical chemistry for the biochemical estimations.

\author{
References \\ ${ }^{1}$ Kannel, W B, Schwartz, M J, and McNamara, P M, Diseases of the Chest, \\ $1969,56,43$. \\ 2 Kannell, W B, et al, Annals of Internal Medicine, 1971, 74, 1. \\ 3 Pelkonen, R, et al, British Medical fournal, 1977, 2, 1185. \\ Kannel, W B, et al, Circulation, 1967, 35, 734. \\ 5 Keys, A, et al, Annals of Internal Medicine, 1972, 77, 15. \\ ${ }^{6}$ Report of a Joint Working Party of the Royal College of Physicians of \\ London and the British Cardiac Society, Fournal of the Royal College of \\ Physicians, 1976, 10, 32.
}

7 Boe, J, Humerfelt, S, and Wedervang, F, Acta Medica Scandinavica, 1957, 157, suppl No 321, p 215.

${ }^{8}$ Stamler, J, et al, Circulation, 1962, 26, 672.

${ }^{9}$ Ostrander, L E, and Lamphiear, D E, Circulation, 1976, 53, 152

${ }^{10}$ Montoye, H J, Epstein, F H, and Kjelsberg, M O, American fournal of Clinical Nutrition, 1966, 18, 397

11 Rappaport, F, and Eichhorn, F, Clinica Chimica Acta, 1960, 5, 161.

12 Lartillot, S, and Vogel, C, Feuillets de Biologie, 1970, 11, No 53, 39.

13 Bruusgaard, A, et al, Scandinavian fournal of Gastroenterology, 1976, 11, 833.

14 Slack, J, et al, British Medical fournal, 1977, 2, 353.

15 Leelarthaepin, B, et al, Lancet, 1974, 2, 1217.

${ }_{16}$ Ashley, F W, and Kannel, W B, Fournal of Chronic Diseases, 1974, 27, 103.

17 Kannel, W B, et al, Annals of Internal Medicine, 1967, 67, 48.

18 Weinsier, R L, et al, American fournal of Medicine, 1976, 61, 815.

19 Mann, G V, New England Fournal of Medicine, 1974, 291, 178.

20 Dahl, L K, American fournal of Clinical Nutrition, 1972, 25, 231.

${ }^{21}$ Keys, A, Henschel, A, and Taylor, H L, American fournal of Physiology, $1947,150,153$.

${ }^{22}$ Fletcher, A P, Quarterly fournal of Medicine, 1954, 23, 331.

\title{
Early deaths in Jamaican children with sickle cell disease
}

\author{
D W ROGERS, JENNIFER M CLARKE, LENA CUPIDORE, ANGELA M RAMLAL, B R SPARKE, \\ G R SERJEANT
}

British Medical fournal, 1978, 1, 1515-1516

\section{Summary and conclusions}

In Jamaican children with homozygous sickle cell (SS) disease diagnosed at birth two-year survival was $87 \%$, compared with $95 \%$ in children with sickle cell-haemoglobin C (SC) disease, and $99 \%$ in normal controls. Death among those with SS disease occurred most often between the ages of 6 and 12 months. Principal causes were acute splenic sequestration and pneumococcal infection.

Neonatal diagnosis of haemoglobinopathies must be followed by close observation if mortality is to be reduced by early diagnosis and treatment of these complications.

\section{Introduction}

Mortality from homozygous sickle cell disease shows considerable geographical variation. In some African populations with a high prevalence of sickle cell trait the rarity of sickle cell (SS) disease in adults can be explained only by high childhood mortality among homozygotes. ${ }^{12}$ In the Belgian Congo (now Zaire) the Lambotte-Legrands ${ }^{3}$ followed 300 children diagnosed at a mean age of 1 year 5 months and reported that $120(40 \%)$ died before the age of 2 .

Higher living standards and improved health care may contribute to the improved survival of homozygotes in North America, but early mortality remains high: Porter and Thurman ${ }^{4}$

\footnotetext{
MRC Laboratories (Jamaica) and Department of Pathology,

University of the West Indies, Kingston 7, Jamaica

D W ROGERS, MRCP, DCH, member of scientific staff

JENNIFER M CLARKE, MRCP, DCH, member of scientific staff

LENA CUPIDORE, SRN, SCM, member of scientific staff

ANGELA M RAMLAL, DM, DCH, member of scientific staff

B R SPARKE, MB, DCP, lecturer in pathology

G R SERJEANT, MD, FRCP, director of MRC Laboratories
}

reported a $16 \%$ mortality in the first year of life among 64 infants diagnosed before the age of 1 . Actual mortality rates may exceed this, since infants die before SS disease is suspected. ${ }^{5}$

Survival of patients with SS disease to adult life is common in the West Indies, but childhood mortality has not been estimated. A cord blood screening programme, started in Jamaica four years ago, has attempted to identify all newborn cases of SS disease in a maternity hospital with about 14000 deliveries a year. Follow-up of these infants has made it possible to calculate a survival curve and to monitor the causes of death.

\section{Methods}

Since July 1973 cord blood samples from Victoria Jubilee Hospital, the main government maternity hospital serving Kingston, have been screened by haemoglobin electrophoresis. ${ }^{6}$ The diagnosis of SS disease was based on the presence of only haemoglobins $(\mathrm{Hb}) \mathrm{S}, \mathrm{F}$, and $A_{2}$ on electrophoresis on both cellulose acetate and agar gel, an $\mathrm{Hb} \mathrm{A}_{2}$ level below $3.2 \%$ at 1 year to exclude sickle cell- $\beta^{0}$-thalassaemia, " and family studies whenever possible. A probable case of sickle cell hereditary persistence of $\mathrm{Hb} \mathrm{F}$ ( $\mathrm{Hb} F$ level of $39.3 \%$ at 1 year; greater than 2 SD above the mean for children with SS disease) was excluded from the study although confirmatory family studies were not possible. The diagnosis of sickle cell-haemoglobin C (SC) disease was based on two major haemoglobin bands in the position of $\mathrm{Hb} \mathrm{S}$ and $\mathrm{Hb} \mathrm{C}$ on electrophoresis on cellulose acetate and agar gel.

From July 1973 to January 197632000 cord blood samples, representing samples from $92 \%$ of all deliveries, were screened, and 109 cases of SS disease and 67 cases of SC disease were detected.

These patients together with 230 age- and sex-matched controls with normal (AA) haemoglobin born in the same hospital were followed prospectively in a special clinic at the University Hospital of the West Indies. Defaulting patients were visited at home when possible. The surviving children were aged from 2 years to 4 years and 6 months on 15 January 1978, the date on which the analysis was based. Survival curves were calculated by the method of Berkson and Gage as described by Armitage. ${ }^{8}$ The method assumes the same mortality in defaulters as in those successfully followed up. Significance levels were calculated from the log rank test. ${ }^{9}$

Necropsies were performed when possible but otherwise the cause of death was deduced from the clinical history and available records. A detailed pathoiogical report of the necropsies is in preparation. 


\section{Results}

During the study 53 (9 SS; 5 SC; 39 AA) of the initial 406 children were lost to follow-up by emigration, removal to remote areas of Jamaica, or default. The percentages of the initial children in each genotype lost to follow up were $4 \%, 1 \%$, and $13 \%$ at one year and $6 \%, 6 \%$, and $16 \%$ at two years for SS, SC, and AA genotypes respectively.

Eighteen children with SS disease, four with SC disease, and three normal controls died. Survival curves for the three genotypes are shown in the figure. Mortality was similar in the different genotypes during the first six months but rose significantly $(P<0.001)$ between 6 months and 1 year in SS disease, half the deaths in children with the SS genotype $(9 / 18)$ occurring during this period. Overall mortality among children with SC disease was higher than in controls $(P<0.05)$. Infant mortality rates (deaths in the first year per 1000 live births) calculated from the survival curve were 95 for SS disease, 30 for SC disease, and 13 for AA controls, compared with an overall infant mortality rate in Jamaica of 26 in 1975 . No deaths have yet been observed after the age of 3 .

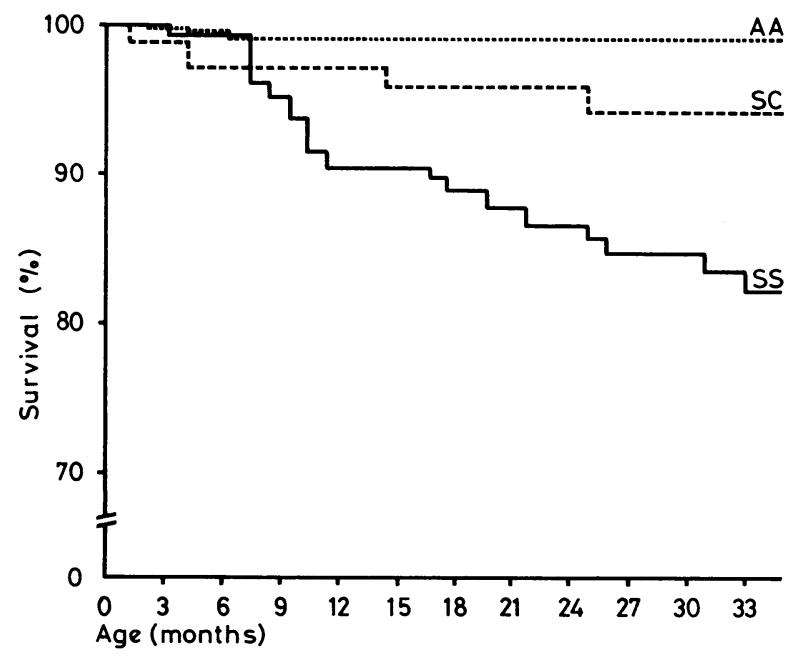

Survival in Jamaican children with genotypes AA, SC, and SS diagnosed at birth.

Cause of death in the 25 patients who died according to age and genotype

\begin{tabular}{|c|c|c|c|}
\hline $\begin{array}{l}\text { Case } \\
\text { No }\end{array}$ & $\begin{array}{l}\text { Age in } \\
\text { months }\end{array}$ & Cause of death & Bacteriological findings \\
\hline \multicolumn{4}{|c|}{$S S$ genotype } \\
\hline$\frac{1}{2}$ & $\begin{array}{l}3 \\
7\end{array}$ & $\begin{array}{l}\text { Gastroenteritis* } \\
\text { Gastroenteritis }\end{array}$ & $\begin{array}{l}\text { No cultures taken } \\
D \text { pneumoniae (middle ear), } \\
\text { pathogenic Escherichia coli (rectum) }\end{array}$ \\
\hline $\begin{array}{l}3 \\
4 \\
5 \\
6 \\
7 \\
8 \\
9\end{array}$ & $\begin{array}{r}7 \\
7 \\
8 \\
9 \\
9 \\
10 \\
10\end{array}$ & $\begin{array}{l}\text { ASS, pneumonia } \\
\text { ASS, pneumonia } \\
\text { Cot death* } \\
\text { ASS } \\
\text { Gastroenteritis* } \\
\text { Pneumonia* } \\
\text { ASS }\end{array}$ & $\begin{array}{l}D \text { pneumoniae (blood) } \\
D \text { pneumoniae (bronchi) } \\
\text { No cultures taken } \\
D \text { pneumoniae (middle ear) } \\
\text { No cultures taken } \\
\text { No cultures taken } \\
\text { No significant growth }\end{array}$ \\
\hline 10 & 11 & $\begin{array}{l}\text { Cardiac failure } \\
\text { (?ASS, } \\
\text { ?septicaemia) }\end{array}$ & No cultures taken \\
\hline 11 & 16 & Meningitis & $\begin{array}{l}D \text { pneumoniae (middle ear), } \\
\text { Salmonella typhimurium (middle ear) }\end{array}$ \\
\hline $\begin{array}{l}12 \\
13 \\
14 \\
15\end{array}$ & $\begin{array}{l}17 \\
19 \\
21 \\
24\end{array}$ & $\begin{array}{l}\text { ASS } \\
\text { Uncertain* } \\
\text { ASS } \\
\text { Uncertain* }\end{array}$ & $\begin{array}{l}\text { No significant growth } \\
\text { No cultures taken } \\
D \text { pneumoniae (blood) } \\
\text { No cultures taken }\end{array}$ \\
\hline $\begin{array}{l}16 \\
17 \\
18\end{array}$ & $\begin{array}{l}25 \\
30 \\
32\end{array}$ & $\begin{array}{l}\text { Pneumonia, } \\
\text { malnutrition } \\
\text { ?Meningitis** } \\
\text { Gastroenteritis, } \\
\text { ASS }\end{array}$ & $\begin{array}{l}\text { No significant growth } \\
\text { No significant growth } \\
\text { No significant growth }\end{array}$ \\
\hline \multicolumn{4}{|c|}{$S C$ genotype } \\
\hline $\begin{array}{l}19 \\
20 \\
21 \\
22\end{array}$ & $\begin{array}{r}1 \\
4 \\
14 \\
24\end{array}$ & $\begin{array}{l}\text { Cot death* } \\
\text { Gastroenteritis* } \\
\text { Gastroenteritis } \\
\text { Gastroenteritis }\end{array}$ & $\begin{array}{l}\text { No cultures taken } \\
\text { No cultures taken } \\
\text { No significant growth } \\
\text { No cultures taken }\end{array}$ \\
\hline \multicolumn{4}{|c|}{ AA genotype } \\
\hline 23 & 2 & $\begin{array}{l}\text { Congenital heart } \\
\text { disease* }^{*}\end{array}$ & No cultures taken \\
\hline $\begin{array}{l}24 \\
25\end{array}$ & $\begin{array}{l}3 \\
6\end{array}$ & $\begin{array}{l}\text { Gastroenteritis* } \\
\text { Gastroenteritis* }\end{array}$ & $\begin{array}{l}\text { No cultures taken } \\
\text { No cultures taken }\end{array}$ \\
\hline
\end{tabular}

*Clinical diagnosis, no necropsy performed. ASS = Acute splenic sequestration.
The causes of death are summarised in the table. Acute splenic sequestration $^{10}$ was diagnosed from sudden splenic enlargement, acute anaemia, and circulatory failure; necropsy findings were an enlarged congested spleen with hypercellular marrow and pallor of the other organs, sometimes with peripheral oedema or pleural effusions. Acute splenic sequestration was the commonest cause death, occurring in seven of the 11 patients for which necropsy results were available.

Blood cultures when reported were performed before or immed ately after death, and further bacteriological specimens were taken at necropsy. Infection with Diplococcus pneumoniae was found in six of the 11 cases for which bacteriology results were available, and in fouf. of these cases acute splenic sequestration had also occurred.

\section{Discussion}

The $13 \%$ mortality in the first two years found in Jamaica $\overrightarrow{0}$ children diagnosed at birth as having SS disease is similar to estimates based on North American experience. ${ }^{45}$ In the first six months mortality in children with SS and SC disease. followed the pattern seen in Jamaican children with AA genoo type, with gastroenteritis as the principal cause of death. In the second six months nearly $10 \%$ of children with SS disease died, mainly with acute splenic sequestration or pneumococcal infecr tion. Further deaths from these causes occurred in childre with SS disease in the second and third years. Deaths fron these causes were not observed in controls or children with $S \mathcal{f}$ disease.

Isolation of the pneumococcus in four cases of acute splenif sequestration suggests that infection with this organism mat play a part in the aetiology of this poorly understood conditione Acute splenic sequestration and pneumococcal septicaemi were both extremely acute in onset, an apparently well child becoming moribund within hours, and this rapid progression may have contributed to the continuing high mortality despit close follow-up. In an attempt to achieve earlier diagnosio mothers were instructed to watch for signs of breathlessness listlessness, or pallor in the child; to check for enlargement of the spleen if easily palpable; and to seek medical attention earl if the child's condition gave any cause for concern. Episodes of acute splenic sequestration and of septicaemia were success fully treated on this basis, by emergency blood transfusion and parenteral penicillin respectively. Penicillin is now given to a patients with acute splenic sequestration because of the risk of underlying pneumococcal septicaemia.

As the principal causes of the high mortality among children with SS disease can be treated by prompt medical intervention this high mortality rate might be reduced by intensive follow-up and careful maternal education. Penicillin prophylaxis and immuo nisation with pneumococcal vaccine also require assessmentos and a trial of these is planned.

We gratefully acknowledge the help of the departments of chil health and microbiology, University of the West Indies, and thank the staff of the Medical Research Council Laboratories and Victoria Jubilee Hospital for their co-operation in the study.

\section{References}

1 Lehmann, H, and Raper, A B, Britısh Medical fournal, 1956, 2, 333.

${ }^{2}$ Jacob, G F, British Medical fournal, 1957, 1, 738.

3 Lambotte-Legrand, J, and Lambotte-Legrand, C, Annales de la Sociét昂

4 Porter, F S, and Thurman, W G, American fournal of Diseases of Childrerg 1963, 106, 35.

5 Powars, D R, Seminars in Hematology, 1975, 12, 267.

${ }^{6}$ Serjeant, B E, et al, Clinical Chemistry, 1974, 20, 666.

7 Serjeant, B E, Mason, K P, and Serjeant, G R, British fournal of Haematology. In press.

${ }^{8}$ Armitage, P, Statistical Methods in Medical Research. Oxford, Blackwe $\stackrel{\Gamma}{+}^{+}$ Scientific Publications, 1974.

${ }^{9}$ Peto, R, et al, British fournal of Cancer, 1977, 35, 1.

10 Seeler, R A, and Schwiaki, M Z, Clinical Pediatrics, 1972, 11, 701.

(Accepted 6 April 1978) 